\title{
PROFESOR WOJCIECH RADECKI DOKTOREM HONORIS CAUSA UNIWERSYTETU ŚLĄSKIEGO
}

\section{PROFESSOR WOJCIECH RADECKI - DOCTOR HONORIS CAUSA OF THE UNIVERSITY OF SILESIA}

Tytuł doktora honoris causa - jako najwyższe wyróżnienie i zarazem wyraz największego uznania ze strony Uniwersytetu Śląskiego - został nadany prof. zw. dr. hab. Wojciechowi Radeckiemu podczas uroczystości, która odbyła się w dniu 16 czerwca 2014 roku w auli numer 8 Wydziału Prawa i Administracji Uniwersytetu Śląskiego w Katowicach. Senat Uniwersytetu Śląskiego uchwałą nr 157 z dnia 24 września 2013 roku uhonorował

* Doktorantka na Wydziale Prawa i Administracji Uniwersytetu Śląskiego.

*** Asystent w Katedrze Prawa Geologicznego i Ochrony Środowiska Wydziału Prawa i Administracji Uniwersytetu Śląskiego. 
Dostojnego Doktoranta najwyższą godnością uniwersytecką, czego uzasadnieniem stały się zasługi Profesora Radeckiego nie tylko dla nauki polskiej, ale mające również wymiar europejski. Ich przedmiotem są nauki prawne w zakresie jednej z najmłodszych, ale rozwijających się niezwykle dynamicznie dyscyplin badawczych, jaką jest prawo ochrony środowiska.

W dyplomatorium uczestniczyły władze Rektorskie i Dziekańskie, członkowie Rady Wydziału, zaproszeni goście, studenci oraz media.

Profesor Wojciech Radecki po ukończeniu studiów prawniczych na Wydziale Prawa Uniwersytetu Wrocławskiego w 1965 roku rozpoczął pracę zawodową w organach prokuratury kolejno jako aplikant, asesor i podprokurator. W tym czasie ujawniła się Jego pasja naukowa, której owocem stało się przygotowanie rozprawy doktorskiej pod kierunkiem Profesora Witolda Świdy p.t. „Odpowiedzialność karna za naruszenie bezpieczeństwa i higieny pracy", obronionej w 1973 r. Uzyskanie stopnia doktora nauk prawnych spowodowało, że związał się zawodowo z Zakładem Prawa Karnego Instytutu Kryminologicznego Uniwersytetu Wrocławskiego. Jego zainteresowania z czasem zwróciły się w kierunku ówcześnie mało znanej problematyki, jaką było prawo ochrony środowiska. Rezultatem tych dociekań stała się rozprawa habilitacyjna pt. „Prawnokarna ochrona środowiska naturalnego w PRL", która została opublikowana w 1981 r. Prezydent Rzeczpospolitej Polskiej nadał Dostojnemu Doktorantowi w 1992 roku tytuł profesora nauk prawnych. Pan Profesor Wojciech Radecki od grudnia 1976 r. rozpoczął pracę badawczo-naukową w Zespole Zagadnień Prawnych Kształtowania i Ochrony Środowiska ówczesnego Instytutu Państwa i Prawa Polskiej Akademii Nauk we Wrocławiu i działał najpierw pod kierunkiem (wtedy jeszcze) docenta dr Jerzego Sommera. Od 2006 r. sam kieruje wrocławskim Zakładem Prawa Ochrony Środowiska Instytutu Nauk Prawnych Polskiej Akademii Nauk. Tym zainteresowaniom naukowym i miejscu pracy Pan Profesor jest wierny do dnia dzisiejszego.

Wojciech Radecki bezspornie uważany jest za jednego z „ojców założycieli” prawa środowiska. Jest On wybitnym specjalistą z zakresu prawa ochrony środowiska oraz prawa karnego 
o niespotykanie bogatym, zróżnicowanym i cenionym dorobku naukowym. W Jego dorobku naukowym znajduje się blisko 160 książek (monografie, komentarze) oraz ponad 2 tysiące różnego rodzaju opracowań naukowych i popularyzatorskich, w znacznej mierze stanowiących podwaliny rozwoju ustawodawstwa, praktyki administracyjnej, jak również poglądów judykatury. Wojciech Radecki jest niekwestionowanym autorytetem z zakresu prawa ochrony przyrody i autorem komentarzy do nieomal wszystkich aktów prawnych istotnych dla prawa ochrony środowiska, a także licznych dzieł o charakterze popularyzatorskim. Profesor jest nie tylko jednym z inicjatorów, organizatorem i uczestnikiem, ale także tłumaczem międzynarodowych konferencji naukowych prawników polskich, czeskich i słowackich zajmujących się prawnymi aspektami ochrony przyrody i środowiska. Wspomnieć należy, że Wojciech Radecki w wieku 60 lat samodzielnie nauczył się języka czeskiego i do dnia dzisiejszego - jak sam zapewnia - każdą niedzielę poświęca na doskonalenie umiejętności z tego zakresu. Profesor przede wszystkim jest niekwestionowanym liderem wśród badaczy prawnych zagadnień ochrony środowiska zajmującym się również tematyką tą w wymiarze unikatowym w polskiej doktrynie prawa czyniąc w kręgu swoich zainteresowań prawa państw środkowoeuropejskich, zwłaszcza Czech i Słowacji. Wojciech Radecki nie stroni również od praktyki stosowania prawa, czego wyrazem są liczne glosy oraz opinie prawne. Od 1996 roku współpracuje z Instytutem Rybactwa Śródlądowego w Olsztynie oraz z Polskim Towarzystwem Rybackim, dla którego napisał Kompendium Prawa Rybackiego. Pełni On także funkcję wiceprezesa w Towarzystwie Naukowym Prawa Ochrony Środowiska.

Recenzentami w postępowaniu o nadanie tytułu doktora honoris causa byli: prof. dr hab. Marek Górski (Uniwersytet Szczeciński), prof. dr hab. Roman Hauser (Uniwersytet im. Adama Mickiewicza w Poznaniu) oraz prof. JUDr. Milan Damohorský (Uniwersytet Karola w Pradze). Wszyscy Recenzenci, oceniając dorobek naukowy Prof. W. R., zgodnie stwierdzili, że nie ma wątpliwości, iż swoim dorobkiem naukowym i popularyzatorskim, a także postawą i całym życiem w pełni wykazał, że zasługuje na uhonorowanie Go najwyższą godnością uniwersytecką. 
Podczas uroczystości sylwetkę Profesora W. Radeckiego w laudacji przedstawił Promotor w postępowaniu o nadanie godności DHC - prof. zw. dr hab. Ryszard Mikosz. Wyraźnie podkreślił On, że to właśnie dzięki działalności Profesora Wojciecha Radeckiego w istocie rzeczy zaistniała polska doktryna prawa ochrony środowiska. Profesor Mikosz wyraził także nadzieję, że przedstawiony obraz dorobku Dostojnego Doktoranta choć w części oddaje rozmiar i głębię Jego dokonań.

Treść dyplomu DHC odczytał Dziekan Wydziału Prawa i Administracji Uniwersytetu Śląskiego prof. dr hab. Czesław Marzysz. Uroczystego wręczenia dyplomu dokonał JM Rektor Uniwersytetu Śląskiego prof. zw. dr hab. Wiesław Banyś. Podczas uroczystości Dostojnemu Doktorantowi wręczono także szklaną statuetkę z wygrawerowanym drzewem (dzieło autorstwa dr hab. Katarzyny Pyki z Instytutu Sztuki UŚ zatytułowane „Drzewo"), która symbolizować ma nie tylko ochronę środowiska, ale również wiedzę, energię, radość, cześć, mądrość, długowieczność oraz nieśmiertelność.

Profesor Wojciech Radecki zaczął od słów: „Nawet gdybym chciał ukryć wzruszenie, to bym nie potrafił. Ani nie chcę, ani nie potrafię [...]. Czuję się zaszczycony i wdzięczny uniwersytetowi właśnie dlatego, że to Uniwersytet Śląski". Następnie wygłosił wykład, który stanowił swoistą „podróż” po ośrodkach naukowych zajmujących się ochroną środowiska w Polsce. Mówił nie tylko o obecnych, ale także wspominał już nieżyjących badaczy, którzy swoją działalność naukową poświęcili nowej dyscyplinie badawczej jaką jest prawo ochrony środowiska. Bowiem - na co zwrócił uwagę - w trakcie ponad ćwierćwiecza niemal wszystkie ośrodki naukowe podjęły rozważania odnoszące się do tej dziedziny.

Oficjalną część dyplomatorium zakończyła pieśń Gaudeamus Igitur wykonana przez Chór Uniwersytetu Śląskiego „Harmonia”. Miłym akcentem i niespodzianką zarówno dla Profesora, jak i dla zebranych gości było odtworzenie utworu muzycznego Marsz Radetzky'ego.

Profesor W. Radecki jest czterdziestą dziewiątą osobą, której Senat Uniwersytetu Śląskiego nadał tytuł doktora honoris causa, jednocześnie jest pierwszym badaczem prawa ochrony 3/2014 środowiska, któremu nadano ten honorowy tytuł. 